Cornell University Law School Scholarship@Cornell Law: A Digital Repository

\title{
Consumer Internet Standard Form Contracts in India: A Proposal
}

Robert A. Hillman

Cornell Law School, rah16@cornell.edu

Follow this and additional works at: https://scholarship.law.cornell.edu/facpub

Part of the Consumer Protection Law Commons, Contracts Commons, and the Internet Law Commons

\section{Recommended Citation}

Robert A. Hillman, "Consumer Internet Standard Form Contracts in India: A Proposal," 29 National Law School of India Review 70-85 (2017)

This Article is brought to you for free and open access by the Faculty Scholarship at Scholarship@Cornell Law: A Digital Repository. It has been accepted for inclusion in Cornell Law Faculty Publications by an authorized administrator of Scholarship@Cornell Law: A Digital Repository. For more information, please contact jmp8@cornell.edu. 


\title{
CONSUMER INTERNET STANDARD FORM CONTRACTS IN INDIA: A PROPOSAL
}

\author{
—Robert A. Hillman*
}

\begin{abstract}
India's burgeoning Internet commerce sector has made consumers susceptible to standard-form contracts. Due to the slim likelihood of consumers reading the terms, vendors may often draft heavy-handed terms in the contracts, thereby adversely impacting consumer interests. The Indian legal framework in this regard is inadequate. This article evaluates the existing suggestions on standard-form contracts and argues that none of them safeguard consumer interests sufficiently. Instead, based on the American Law Institutes' Principles of the Law of Software Contracts, the article proposes a disclosure approach that would benefit the interests of Indian consumers engaged in commerce on the internet.
\end{abstract}

\section{INTRODUCTION: THE GENERAL PROBLEM WITH CONSUMER INTERNET STANDARD-FORM CONTRACTS}

In an ideal world, Internet standard-form contracts between vendors and consumers would be beneficial to both parties. ${ }^{1}$ Through trial and error, the vendor would draft an agreement that allocates the various risks most efficiently and vendors would pass along some of the savings to consumers. In addition, consumers would shop for their array of needs from the comfort of their home at a convenient time. ${ }^{2}$ However, in the real world, there are reasons to be wary of Internet standard terms (hereinafter e-standard terms). The main problem is that

* The author is the Edwin H. Woodruff Professor of Law at Cornell University Law School. He extends his thanks to Sital Kalantry for reading a draft of this article and offering valuable feedback.

1 "E-commerce is expected to improve the productivity and competitiveness of participating businesses by providing unprecedented access to an on-line global market place with millions of consumers and thousands of products and services." Bhanu Srivastava, Balendu Bhushan, Legal Issues Involved in E-Contracts, ACADEMIKE (Jan. 30, 2015), http://www.lawctopus.com/academike/ legal-issues-involved-e-contracts/.

2 Kavha Mathur, Position of Electronic Contracts in India, Racolb Legal (Apr. 16, 2016), http:// racolblegal.com/position-of-electronic-contracts-in-india/. 
few consumers read them before completing a transaction, which invites some vendors to draft one-sided terms - anissue also common in the world of paper contracts, but exacerbated in the digital world. ${ }^{3}$

In fact, consumers have good reasons to give at most short shrift to their e-standard terms. ${ }^{4}$ Forms are long, full of legalese, and consumers rationally believe that nothing is likely to go wrong, and so they abandon reading. Further, despite the luxury of shopping at home, often without serious time constraints, consumers have become attuned to speed and efficiency, and seek to click through an agreement as fast as possible. Vendors can add to the likelihood that consumers will decline to read by writing impenetrable boilerplate, by hiding controversial terms on the website and within the e-standard form itself, and by experimenting with presentations of the e-standard terms to find an approach that deters reading as much as possible. ${ }^{5}$

In the absence of any concern about adverse market forces, vendors can therefore take advantage of consumers in various ways. Vendors can write terms that are especially disadvantageous to consumers. For example,terms that create inconvenient venues for litigation or arbitration in far-off places and before less than neutral industry arbitrators; that allow for unilateral modification; that permit automatic renewal of subscriptions and licenses. ${ }^{6}$

Indiais no exception to the rise of Internet contracting. ${ }^{7}$ The convenience of, and bountiful choices made available through Internet shopping, along with

See Principles of the Law of Software Contracts $\$ 2.01$ at 113 (American Law Institute 2010) (hereinafter ALI Principles): "Boilerplate is often incoherent. Transferees have little bargaining power and few alternatives because transferors have few competitors or because competitors offer similar terms. Transferees have only a limited capacity to digest information and often rely on strategies that simplify decision making or even rely on intuition and hunches. They also often underestimate the probability (although low) of adverse events. Although many transferees who are downloading software or opening a software package have the luxury of reading the terms in their homes in the evening, and are therefore free of manipulative sales agents and other distractions, transferees may not assign the same significance to a mouse click or terms presented after payment as they do to a signature on a paper standard form presented prior to payment."; See also Robert A. Hillman, Online Consumer Standard Form Contracting Practices: A Survey and Discussion of Legal Implications, in Consumer Protection in the Age of the 'Information EConomy' 283 (Jane K. Winn, ed. 2006).

4 See Robert A. Hillman and Jeffrey J. Rachlinski, Standard-Form Contracting in the Electronic Age, 77 N.Y.U. L. Rev. 429 (2002).

Id. at $478-480$.

6 For another example, Internet software vendors confuse consumers by warranting the quality of their products on their websites and then disclaiming them on their e-standard forms. In this article, we therefore concluded that in the digital age bait-and-switch is a real problem in the area of software product warranties. Robert A. Hillman \& Ibrahim Barakat, Warranties and Disclaimers in the Electronic Age, 11 Yale J.L. \& Tech. 1 (2009).

"India is a major player in the computer software and resources sector." Simran Shah, E-Contracts and Issues Involved 8 (July 9, 2014) at http://www.academia.edu/8719077/E Contracts_and_Issues_Involved.In fact, one author predicted that by the end of 2014 "India will have the largest number of internet-users in Asia in the near future." Neeta Ghadge, A Study 
a rapid developing economy and rising living standards has fueled a dramatic increase in shopping on the Internet. ${ }^{8}$ Although India is one of the most culturally diverse countries in the world, this article will assume that on the issue of reading of e-standard forms, India's shoppers as a whole are no more eager readers of e-standard forms than those in rest of the world. ${ }^{9}$ On the other hand, India's businesses negotiate contracts cautiously and negotiations are often painstakingly deliberated. ${ }^{10}$ Successful business negotiators must be patient and unhurried. ${ }^{11}$ If Indian Internet consumers exhibit similar cautious and deliberative tendencies, they may pay more attention to their e-standard forms. However, without the possibility of negotiating with vendors, presented with long and technical e-standard terms, and likely optimistic that nothing will go wrong, Indian consumers probably more closely resemble non-readers in the US than Indian business people. Further, Indian court decisions may be delayed and enforcement is sometimes problematic. $^{12}$ Consumers therefore cannot rely on judicial protection through doctrines such as unconscionability and public policy to protect them from unfair e-standard terms. With these assumptions-aburgeoning Indian Internet commerce, Indian consumers failure to read, and delayed justice-the problem of assent to e-standard forms demands attention in India as well as elsewhere.

Scholars in India have referred to U.S. courts' labelling of two main types of presentations of e-standard terms, each raising enforcement issues dealing with adequacy of notice and whether the consumer has manifested assent to the e-standard form. ${ }^{13}$ "Click wrap" presentations require the consumer affirmatively

of Formation and Challenges of Electronic Contract in Cyberspace, LEGAL SERvices INDIA (December 12, 2015) at http://www.legalservicesindia.com/article/article/a-study-of-formationand-challenges-of-electronic-conract-in-cyberspace-1943-1.html.

8 See, Amrish Rau, E-Commerce in India-Understanding its Uniqueness, ICICI Merchant Services, Business Standard (Oct. 24, 2011 )http://www.business-standard.com/article/press-releases/e-commerce-in-india-understanding-its-uniqueness-111102400096_1.html: "India has close to 10 million online shoppers and is growing at an estimated $40-45 \%$ rate."; Shah, supra note 7: "With the advancements in computer technology, telecommunication and information technology the use of computer networks has gained considerable popularity in the recent past ** *."); Ghadge, supra note 7:" Today's computerized generation need more protection. *** It is quite unlikely for most computer literate people in India that a day has passed without him or her coming across a point while dealing with computers where he or she did not have to manifest his or her assent to some terms." ;Id.

9 A very casual survey of Cornell Law School's LLM students from India in the fall of 2016 suggests little difference between consumer behavior in India and elsewhere. Researchers should confirm this and address the education levels, wealth, and patience of typical e-consumers, among other things.

10 Alliance Experts, Indian Business Culture, Contract Law and Negotiations, at http://www.allianceexperts.com/en/knowledge/countries/asia/indian-contract-law-and-how-it-affects-your-business/

11 Id.

12 Aparna Chandra, William H.J. Hubbard, \& Sital Kalantry, The Unintended Consequences of Case-by-Case Rescue: An Empirical Study of Indian Supreme Court Cases from 2010 to 2014, (Presented at the Legal Theory Workshop Spring 2017 Session, Columbia Law School, New York on Feb. 27, 2017).

13 See Ghadge, supra note 7; For recent U.S. cases on browse wrap and click wrap, see,e.g., Facebook Biometric Information Privacy Litigation,In re, 2016 WL 2593853, at 6 (ND Cal 2016); 
to click "I agree"or the like adjacent to or below the terms in order to complete a transaction. ${ }^{14}$ In "browse wrap" transactions, on the other hand, the consumer sees a screen that directs the consumer to a separate screen or screens that contain the terms. A consumer can "agree" to the terms without ever seeing them, no less reading them. ${ }^{15}$ In fact, some websites declare that the very act of visiting the website constitutes acceptance of the terms presented on another screen. Courts in such situations generally require "actual or constructive knowledge" of the terms before enforcing them. ${ }^{16}$

Notwithstanding the protection afforded to consumers by click wrap and browse wrap judicial approaches, each presents legal issues that have not been adequately addressed. The browse wrap technique is problematic and has met with some resistance in U.S. courts because vendors can hide terms or at least deflect attention from them, including by manipulation of graphics and font sizes and requiring challenging searches through screens to find the terms. ${ }^{17}$ In short, browse wrap often does not sufficiently alert consumers to what they are supposedly agreeing to. ${ }^{18}$ Of course, even if a consumer can find the e-standard form easily, the problem remains that consumers rarely read the terms and few bring actions to fight off unfair terms. Click wrap transactions mirror paper standard form transactions and U.S. courts have more readily enforced them, but the presentation also suffers from the reality that few people read their e-standard contracts. The problem is exacerbated on the Internet because few consumers "are

Nguyen v. Barnes \& Noble, Inc., 763 F3d 1171, 1173 (9th Cir 2014).

14 Clickwrap agreements are similar to the process of signing a paper standard form and are generally enforced by U.S. courts. See, e.g., Berkson v. Gogo LLC, 97 F Supp 3d 359, 397 (EDNY 2015) (clickwrap "require[s] a user to affirmatively click a box on the website acknowledging awareness of and agreement to the terms of service before he or she is allowed to proceed with further utilization of the website."); Barnett v. Network Solutions, Inc., 38 SW3d 200, 204 (Tex. Ct. App. 2001); Caspi v. Microsoft Network LLC, 732 A2d 528, 532 (N. J. Super. Ct. App. Div. 1999). But a button that simply says "register" should be insufficient even if otherwise a clickwrap agreement. See Meyer, v. Kalanick, 2016 WL 4073012, at*6 (SDNY 2016).

In India, clickwrap agreements are sometimes referred to as "click to agree" contracts. Seesupra note 7.

15 U.S. courts treat browsewrap agreements with suspicion, see, e.g., Specht v. Netscape Communications Corpn., 306 F3d 17, 32 (2nd Cir 2002), but not always. See, e.g. Register.com, Inc. v. Verio, Inc., 356 F3d 393 (2nd Cir 2004).

16 Nguyen v. Barnes \& Noble, Inc., 763 F3d 1171, 1176 (9th Cir 2014).

17 See, e.g., Meyer, v. Kalanick, 185 F Supp 3d 448 :2016 WL 4073012, at *6 (SDNY 2016); Hillman \& Rachlinski, supra note 4 , at 481-82:" Studies of e-commerce confirm the suspicion that the Internet is not yet a consumer's paradise. In theory, the easy access to information that the Internet provides should reduce prices and reduce price dispersion between businesses that supply similar goods. Although e-commerce has had this effect on some commodities, wide dispersions in prices can be found. In some cases, the disparities are no lower on the Internet than in the real world. These results indicate that e-consumers have yet to exploit the full benefits of the electronic environment. Despite the Internet's apparent benefits for consumers, these findings reveal that businesses still have many opportunities to exploit consumers' lack of information about goods and services."Id. at 473-74.

18 See, e.g., Specht v. Netscape Communications Corpn., 306 F3d 17, 32 (2nd Cir 2002)(browsewrap not enforceable); but see Register.com, Inc. v. Verio, Inc., 126 F Supp 2d 238, 248 (SDNY2000), aff'd, 356 F3d 393 (2nd Cir 2004) (browsewrap enforceable). 
likely to read and digest terms in a medium conducive to speed, instant gratification, and manipulation." 19 It is therefore often a leap to say that consumers consent to either formation approach even by clicking "I accept." 20

\section{THE LEGAL TREATMENT OF E-STANDARD FORMS IN INDIA}

The quagmire of what should constitute assent to e-standard forms is not limited to the United States, where the failure to read is well-documented, but is at least a potential problem world-wide. ${ }^{21}$ As already noted, Internet shopping in India is rising dramatically. ${ }^{22}$ However, India does not have comprehensive rules to ensure valid assent to e-standard terms. ${ }^{23}$ The Indian Contract Act of 1872 , largely a codification of the common law, obviously does not deal directly with this modern problem. ${ }^{24}$ Its general rules, including offer and acceptance, unconscionability, public policy, and fraud only indirectly relate to modern Internet contracting. ${ }^{25}$ Nevertheless, such rules may prove satisfactory in some settings. For example, in India, actions calculated to deceive qualify as fraud. ${ }^{26}$ If vendors create difficulties in reaching a screen that sets forth the e-standard terms or hide unfair terms within the e-standard form, the terms may be unenforceable on the grounds of fraud. However, producing evidence of intent to deceive may be difficult. ${ }^{27}$ India also regulates the fairness of contracts and the quality of assent

19 ALI Software Contracts, supra note 3, at 115. See also id.at 122: "But even click wrap raises concerns over the presentation of the terms (for example, must the terms be available on the same page as the "I agree" icon or will a nearby scroll box or hyperlink do?)"

20 See, e.g., Jerez v. JD Closeouts LLC, 943 NYS2d 392 (D.Ct. Nassau Co. 2012); Tres Jeanee, Inc. v. Brolin Retail Systems Midwest, Inc., 2007 WL 3118482 (WD Ky 2007); ESL Worldwide.com, Inc. v. Interland, Inc., 2006 WL 1716881 (SDNY); Person v. Google, Inc., 456 F Supp 2d 488 (SDNY 2006); Hotels.com, LP v. Canales, 195 SW3d 147 (Tex. Ct. App. 2006). Nevertheless, at least one author argues that in India "click-wrap agreements are valid, enforceable contracts."Vimlendu Tayal, Cyber Law, Crber Crime, Internet and E-Commerce430 (2011).

21 "[T]here are no specific definite *** rules protecting the transaction happening over the electronic medium." Kavha Mathur, Position of Electronic Contracts in India, 3, RaColB LeGAL (Apr. 16, 2016), http://racolblegal.com/position-of-electronic-contracts-in-india/. See also Shah, supra note 7; See also Ghadge, supra note 7:"Determining jurisdiction and formation of e-contracts are two key issues on which traditional legal principles have been largely applied by Courts [in India]."

22 See supra notes 7-9.

23 However, contracts cases in India under the Indian Contract Act, 1872 have focused on bargaining power, an obvious issue under take-it-or-leave-it e-standard forms. See Blog, E-Contracts in India AgAma Law Associates, https:/archanabala.com/2015/06/03/e-contracts-in-India.

24 Nilima Bhadbhade, The Indian Contract Act, 1872, 119 (2015).

25 Ghadge, supra note 7: The Indian Contract Act, 1872 gives a statutory effect to the basic common law contractual rule that a valid contract may be formed if it is made by free consent of the parties, competent to contract, for a lawful consideration and for a lawful object and which is not void ab initio."). See also Shah, supra note 7 .

26 Indian Contract Act, 1872, Sections 14 and 17.

27 A further roadblock is that India does not recognize a good-faith obligation in negotiating a contract. Bhadbhade, supra note 24 , at 63 . 
through the principles of unconscionability and public policy. ${ }^{28}$ However, without more, unconscionability and public policy are amorphous terms and therefore are unreliable to police e-commerce. ${ }^{29}$ Equally, the rules of offer and acceptance may be too general to guide decision makers as to the propriety of screen presentations of terms. ${ }^{30}$

Each of the above regulating tools also suffers from reliance on after-the-fact policing and will do nothing to decrease the costs of dispute resolution and will potentially bury the courts of litigation. Thus, although potential checks against enforcement of unfair e-standard terms exist in the Indian Contract Act, the legislation may be only a limited solution to the issue of consumer assent in Internet transactions. Because consumer confidence, including confidence that the vendor is not overreaching, is a prerequisite to growing Internet commerce, a more comprehensive and direct solution would be beneficial to India's economy. ${ }^{31}$

The problem of consumer failure to read e-standard terms and the potential for vendor opportunism in India and elsewhere across the world therefore demands additional attention. ${ }^{32}$

In the next part, I discuss and evaluate proposed solutions.

\section{PROPOSED SOLUTIONS}

To date, writers have addressed the problem of consumer assent and vendor opportunism in e-commerce both in India and elsewhere. Some solutions are designed to increase the opportunity to read e-standard terms, while others rely on post-contract policing. Each proposed solution is problematic for various reasons. For example, the law could establish a cooling-off period, in which consumers could change their minds and rescind their commitment. However, the lack of finality would be costly to vendors who would pass on these costs to consumers. In addition, as noted elsewhere, "ironically, establishment of a cooling-off period may even discourage reading by lulling transferees into believing they can always return or remove the product from their computer if something goes wrong." ${ }^{33}$

Another possible solution would be for the law to mandate protective terms that are most important to consumers. However, this approach would compromise freedom of contract and would raise questions about what terms should

28 Indian Contract Act, 1872, Sections 16(3) and 23. See also E-Commerce in India (Nishith Desai Associates), https://archanabala.com/2015/06/03/e-contracts-in-India.

29 See, e.g., Robert A. Hillman, Debunking Some Myths About Unconscionability: A New Frameork for U.C.C. Section 2-302, 67 CORNell L. Rev. 1 (1981).

30 See Indian Contract Act, 1872, Sections 2 and 7.

31 Rau, supra note 8.

32 R.K.Chaubey, An Introduction to Cyber Crime and Cyber Law 657 (2008).

33 ALI Principles, supra note 3, at 117. 
be mandatory. The possibility that regulators would fail to correctly identify the kinds of terms that would overreach is real. Candidates for regulation would include terms relating to choice of law, forum selection, warranties, automatic renewal, privacy and modification. But the size of this list already is a worrisome encroachment on autonomy and would likely continue to grow in many contexts.

Another approach suggested in academic writing is to require vendors to highlight problematic terms in bold or to closet them in a special box. ${ }^{34}$ Again, the selection of terms to highlight or box would challenge regulators. Terms mentioned above as candidates for mandatory inclusion suggest that regulators would face a challenge keeping manageable the number of terms especially treated. Otherwise, the highlighted or boxed terms will resemble the entire agreement and will lose the promise of enhanced attention by consumers. There is a real possibility that consumers, who are accustomed to speed, will fail to read even conspicuous terms and will skip over the boxed terms.

Still another strategy would be to require consumers to click "I agree" next to all of the contentious terms. However, contract formation would become onerous and consumer ability to "speed click" through the terms suggests that little additional reading would result. ${ }^{35} \mathrm{Clicking}$ "I agree" numerous times may be especially problematic in India, where the very simplicity of entering into contracts digitally facilitates the increased growth of Internet commerce. ${ }^{36}$

Another approach would be to deemphasize or even abandon the requirement of disclosure of terms in their entirety and to rely on rules such as unconscionability to police exchanges for unfairness once a dispute arises. In addition to the reality that at least in the U.S., unconscionability has largely been unsuccessful in corralling advantage-taking by unscrupulous vendors, ${ }^{37}$ such an approach is obviously a dramatic limitation on the notion of manifest assent: "The idea of individual assent is obviously more robust when transferees have a reasonable opportunity to read and compare terms." ${ }^{38}$ In fact, such an approach devalues the rule of law itself:

"A fundamental tenet of the rule of law is reasonable notice. For example, in criminal law, "fair warning" requires that the law "explicit[ly] [ ] inform those who are subject to [the law] what conduct on their part will render them liable to its penalties."

34 See, e.g., Aaron Perzanowski \& Chris Jay Hoofnagle, What We Buy When We Buy Now, 165 U. PA. L. REv. (forthcoming 2017) (authors relate concerns about consumers' understanding of their legal rights when they license a book or movie and suggest a box explaining those rights).

35 Hillman and Barakat, supra note 6. ("E]xtra clicking would be cumbersome for little gain because consumers would simply click without digesting the disclaimer.").

36 Rau, supra note 8.

37 Robert A. Hillman \& Maureen O'Rourke, Defending Disclosure in Software Licensing, 78 U.Chi.L. Rev. 95, 105 (2011).

38 ALI Principles, supra note 3, at 132. 
The goal is to "give the person of ordinary intelligence a reasonable opportunity to know what is prohibited." Yet we all know that people rarely read criminal statutes or understand many of the intricacies of rules governing even those wrongs of which they are aware, such as murder or theft. The point is that people could gain access to these materials, which legitimizes the rules as law." ${ }^{39}$

Another reason for caution before devaluing or even eliminating the requirement of disclosure of terms is that an opportunity to read terms gives at least some credence to the notion that consumers give"blanket assent" to reasonable standard terms even when they do not read them. "Blanket assent" means that consumers understand that they will be bound to reasonable terms although they decide not to read them. ${ }^{40}$

Finally, some analysts have suggested that public or private rating services could evaluate terms and post the ratings on the Internet. ${ }^{41}$ This approach depends, of course, on whether consumers would make use of the ratings. The evidence is encouraging. Private watchdog groups consist of voluntary rating services and have already had some success in calling attention to nasty terms ${ }^{42}$ Part IV of this paper, which follows, emphasizes the potential role of rating services/watchdog groups and suggests that the strategy of early disclosure of e-standard terms could facilitate their effectiveness. The American Law Institute's "Principles of the Law of Software Contracts" (hereinafter ALI Principles) adopts this approach. ${ }^{43}$ The ALI framework, although focused on software, need not be so limited.

39 Hillman and O'Rourke, supra note 37 at 105-106.

40 This idea is Karl Llewellyn's. See Hillman and Rachlinski, supra note 4, at 492 ("If e-consumers have some opportunity to read the standard terms before deciding whether to enter into the contract, then courts should apply Llewellyn's presumption of enforceability of such terms. Just as in the paper world, consumers understand the existence of standard terms and agree to be bound by them, even though they rarely choose to read them.").

${ }^{41}$ See Omri Ben-Shahar, The Myth of the "Opportunity to Read" in Contract Law, 5 Eur. Rev. Contract L. 1 at 22-25 (2009).

42 See infra note 46.

43 The author of this paper was the Reporter (chief drafter) of the ALI Principles. The American Law Institute's homepage describes the organization: "The American Law Institute is the leading independent organization in the United States producing scholarly work to clarify, modernize, and otherwise improve the law." American Law Institute, https://www.ali.org/ (December 19, 2016). U.S. courts often cite and follow the ALI's many works, including its Restatements and Principles projects. 


\section{THE APPROACH OF THE AMERICAN LAW INSTITUTE'S PRINCIPLES OF THE LAW OF SOFTWARE CONTRACTS}

In this Part, I argue that the modest (but more realistic) solution suggested by the ALI Principles may have some resonance in India and other countries seeking to respond to issues raised by Internet contracting. The approach of ALI depends in part on the traditional objective test of assent, but it goes much further to advocate early disclosure of terms on the vendor's website, even before a consumer initiates a particular transaction. U.S. law does not require such advanced disclosure; neither do the ALI Principles. However, the ALI Principles set forth early disclosure as a "best practice" that would encourage vendors to disclose their terms because it would increase the likelihood of their enforcement. ${ }^{44}$ The ALI Principles also call for a more robust judicial exercise of policing tools, including unconscionability and public policy, despite the limitations of these principles.

Though the efficacy of such a requirement would still depend on the number of customers reading e-contracts, at least two reasons make increased disclosure a desirable strategy. First, as noted above, the opportunity to read is a necessary condition before a legal system can justify the enforcement of its rules. ${ }^{45}$ Second, rating services/watchdog groups (of which there are many on the Internet ${ }^{46}$ ) would have better access to terms and could publicize the Internet vendors' use

${ }^{44}$ See Jean Braucher, Delayed Disclosure in Consumer E-Commerce as an Unfair and Deceptive Practice, 46 WAYNE L. REv. 1805, 1806-07 (2000) (reporting the author's finding that 87.5\% of software companies did not make pre-contract disclosures of their terms). Still, there is a growing literature on the futility of disclosure. See, e.g.,Ben-Shahar,supra note 41;Clayton P. Gillette, Rolling Contracts as an Agency Problem, 2004 WIs. L. REv. 679, $687-88$ (2004) ("It is unlikely that the Internet buyer will devote more time to reading text on the website than more traditional buyers devote to reviewing the terms of tangible [standard forms].").

45 See supra notes 38 and 39. "[T]he importance of the common law principle of stare decisis does not depend on the proposition that people actually know and understand precedent, but on the notion that the legal texts are available to them." Robert A. Hillman \& Maureen O'Rourke, Defending Disclosure in Software Licensing, 78 U. CHI. L. Rev.95, 105 (2011).

46 The ALI Principles discuss watchdog groups in the Reporters' Notes. See ALI Principles, supra note 3 at $141 \mathrm{cmt}$. e:" For a general discussion of watchdog groups, see Ronald Chen \& Jon Hanson, The Illusion of Law: The Legitimating Schemas of Modern Policy and Corporate Law, 103 Mich. L. Rev. 1, $53-54$ (2004) ('Consumer-oriented groups, such as the Consumers Union, act as informers and watchdogs on behalf of consumers.'). E-watchdog groups include the Electronic Frontier Foundation, which lists 'dangerous terms' commonly found in licensing agreements, including those that bar criticism of products, permit monitoring of a transferee's computer, and allow modification of agreements without notice or consent. See Annalee Newitz, Dangerous Terms: A User's Guide to EULAs, Electronic Frontier Foundation, http://www.eff. org/wp/eula.php. See also Larry Magid, It Pays to Read License Agreements, PC PIтsToP, http:// www.pcpitstop.com/spycheck/eula.asp discussing the licensing agreement that accompanies Gain Publishing's eWallet software, which authorizes the collection of data about a consumer's reading behavior, TV interests, and communication partners, effectively allowing the company to 'follow [the transferee] around." 
of problematic terms. This would incentivize vendors to draft reasonable terms in the first place in order to establish and preserve goodwill. ${ }^{47} \mathrm{~A}$ demonstration of this was on witness when Facebook's gambit to diminish its users' privacy rights caused it to retract the offensive terms generated widespread negative publicity. This incident serves as an example of what rating services/watchdog groups can accomplish, and how wider accessibility of e-standard terms facilitates the watchdog process itself. ${ }^{48}$

The ALI Principles implement the disclosure strategy in Sections 2.02(b) and (c) ${ }^{49}$ Section 2.02 , in pertinent part states:

\$ 2.02 Standard-Form Transfers of Generally Available Software; Enforcement of the Standard Form

(a) $* * *$

(b) A consumer adopts a standard form as a contract when a reasonable [vendor] would believe the [consumer] intends to be bound to the form.

(c) A [consumer] will be deemed to have adopted a standard form as a contract if

(1) the standard form is reasonably accessible electronically prior to initiation of the transfer at issue;

(2) upon initiating the transfer, the [consumer] has reasonable notice of and access to the standard form before payment or, if there is no payment, before completion of the transfer;

(3) * * *the[consumer] signifies agreement at the end of or adjacent to the electronic standard form ***.

(4) the[consumer] can store and reproduce the standard form if presented electronically.

47 See Hillman \& Rachlinski, supra note 4, at 469-70 \& n.222; Avery Wiener Katz, Standard Form Contracts, in 3 New Palgrave Dictionary of Economics and the Law 502, 505 (Peter Newman ed., 1998) ("If reputational concerns lead drafters of forms to moderate their opportunism, regulation may be largely unnecessary.").

48 See, e.g., Eric Auchard, Facebook alters notifications after privacy furor,ReUTERs (Nov. 30, 2007), http://www.reuters.com/article/us-facebook-privacy-idUSN2925736120071130

49 ALI Principles, supra note $3, \S 1.01(1)$ at 11 .Section 2.02 applies to what the Principles call "standard-form transfers of generally available software." In part, these are transfers that target consumer transactions and apply when a licensor transfers a small number of copies of software to an end user if the software "is generally available to the public under substantially the same standard terms." 


\section{A. Subsection 2.02(b)}

Subsection 2.02(b) does nothing more than adopt the objective test of contract formation, the general approach in common-law countries. ${ }^{50}$ The subsection obviously does not create a bright-line rule of what constitutes assent. Instead, it allows for various screen presentations that may pass muster depending on the circumstances. The test is simply whether it is reasonable to believe the consumer intends to be bound to the terms. Click wrap presentations should meet the test so long as the consumer clicks "I agree" at the bottom of or adjacent to the terms. Hyperlinks sending the consumer to various additional screens, under a browse wrap process, are more problematic under this test, ${ }^{51}$ but subsection 2.02(b) would not exclude them if, for example, a consumer has a long history of doing business with the vendor under a browse wrap process.

To illustrate, suppose Raj is shopping to purchase some books on Barnes \& Noble's website. ${ }^{52}$ Raj can reach the Terms of Use only by clicking on a hyperlink located at the bottom of each page of the website, but the hyperlink is surrounded by other hyperlinks. Raj does not click on the Terms of Use hyperlink nor read the terms, but instead selects the books and checks out by clicking "purchase" to complete the sale. The Terms of Use includes a term stating that "[b]y visiting any area in the Barnes \& Noble.com Site, creating an account, [or] making a purchase via the Barnes \& Noble.com Site ***a User is deemed to have accepted the Terms of Use." The Terms of Use include an arbitration clause. ${ }^{53}$ Under Section 2.02(b), the issue would be whether a reasonable vendor would believe Raj intended to be bound to the terms, including the arbitration provision. In turn, this would depend on whether the website provided a reasonable notice of its terms of use, and whether Raj manifestedan intention to be bound to the terms. ${ }^{54}$ A U.S. court, under similar facts, refused to enforce the arbitration provision, ${ }^{55}$ concluding that even if the hyperlink leading to the Terms of Use was conspicuous, it was insufficient to constitute constructive notice of the arbitration provision in the absence of a prompt requiring the consumer to take affirmative action in order to consent..$^{56}$ On the other hand, if Raj had contracted previously

so See, e.g., Restatement Second, Contracts $\$ \S 20$ and 50.

51 Gary M. Olson \& Judith S. Olson, Human-Computer Interaction: Psychological Aspects of the Human Use of Computing, 54 ANv. REv. PsychoL. 491, 500 (2003) "There are design prescriptions gleaned from empirical studies of web-searching behavior that claim that if in three clicks users do not find information that at least suggests they are on the right track, they will leave the site."

52 The Raj illustration is based on Nguyen v. Barnes \& Noble, Inc. 763 F3d 1171, 1176 (9th Cir 2014).

53763 F3d 1171, 1173 (9th Cir 2014).

54763 F3d 1171, 1173 (9th Cir 2014).

55 Nguyen v. Barnes and Noble, Inc. $763 \mathrm{~F} 3 \mathrm{~d} 1171,1176$ (9 $^{\text {th }}$ Cir 2014).

56 $763 \mathrm{~F} 3 \mathrm{~d} 1171,1178-1179$ (9th Cir 2014).“[W] here a website makes its terms of use available via a conspicuous hyperlink on every page of the website but otherwise provides no notice to users nor prompts them to take any affirmative action to demonstrate assent, even close proximity of the hyperlink to relevant buttons users must click on -without more-is insufficient to give rise to construction notice." 
with Barnes and Noble on the Internet and actually knew how to find the terms, the case would come out differently under subsection 2.02 (b).$^{57}$

An Indian court would have to massage the Indian Contract Act, 1872 to reach a result for Raj. Although Sections 2 and 3 of the Act do not address click wrap and browse wrap issues directly, the sections invite inquiry on whether a finding of assent is appropriate. Subsection 2(b) of the Act states that "when the person to whom the proposal is made signifies his assent thereto, the proposal is said to be accepted." ${ }^{8}$ This provision, of course, does not shed much light on whether clicking "I accept" or the like "signifies assent." But it does suggest that the test of assent in India does not require actual knowledge of the terms and therefore the focus should be on whether clicking "I agree" is sufficient to signify assent. Similarly, Section 3 provides: "The communication of *** the acceptance of proposals ***are deemed to be made by any act or omission of the party ** * accepting *** by which he intends to communicate such ***acceptance, or which has the effect of communicating it." 59 The latter phrase, "has the effect of communicating it" also requires an objective inquiry into whether there has been a reasonable communication of acceptance. If Raj was reasonable in failing to follow the hyperlink to the terms, Raj would have a viable argument that he has not accepted them under Sections 2(b) and 3.

Because of the inherent uncertainty of the objective test of assent in section 2.02(b) of the ALI Principles, a vendor that does not want to risk an adverse finding on consumer assent to the terms can follow section 2.02(c) to increase the likelihood of a finding in its favour. This subsection incentivises vendors to disclose their e-standard terms on their website before any particular transaction. We now turn to this subsection.

\section{B. Subsection 2.02(c)}

The preamble to subsection (c), "a consumer will be deemed to have adopted a standard form as a contract if", encourages vendor "best practices" that will increase the likelihood of enforcement of its e-standard terms barring a defense based on unconscionability or the like. But the language of the preamble clearly does not require the vendor to follow the subsection.

Subsection (c) consists of several requirements. Comment $c$ to Section 2.02 explains:

"The standard form must be reasonably accessible electronically prior to any particular transaction ***; upon initiation

See supra notes 51-52.

58 Indian Contract Act, 1872, Section 2(b).

59 Indian Contract Act, 1872, Section 3. 
of a transaction, the transferee must receive reasonable notice of and access to the standard form prior to payment or completion of the transaction; the transferee must signify agreement at the end of or adjacent to an e-standard form ***; the terms must be reasonably comprehensible; and electronic terms must be capable of storage and reproduction, such as by printing a hard copy." ${ }^{60}$

\section{(a) Subsection 2.02(c)(1)}

This subsection is the heart of the ALI Principles' strategy to create a stronger incentive for vendors to draft reasonable terms. Under subsection (c)(1), the terms must be "reasonably accessible electronically" before a consumer such as Raj initiates a transaction. Initiation occurs when Raj begins the process of acceptance, for example, by clicking on a "purchase" or "buy now" icon that precedes the request for payment information."Reasonably accessible" means that the e-standard form must be available to read for a reasonable time prior to this initiation. As mentioned, an important goal of Section 2.02(c) is to ensure that the terms are accessible to private rating services/watchdog groups, which should influence a decision maker's view of what is a reasonable time under the particular circumstances. More specifically, the terms must be accessible for a sufficient time so that the rating service/watchdog group can spread the word about terms that overreach.

The ALI Principles also explain that accessibility requires reasonable notice of the terms, typically on the vendor's homepage, with instructions on how to access the e-standard form. A reasonable notice would be satisfied if "a visitor to the site could not help but see the notice."'61

\section{(b) Subsection 2.02(c)(2)}

In order to differentiate the requirements of subsections (c)(1) and (c)(2), the comment to subsection (c)(2) compares the requirements:

"Subsection (c)(1) requires a [vendor] to maintain a web presence and to post its terms prior to any particular transaction. A [consumer] could then see terms without entering any transaction at all. Subsection (c)(2), on the other hand, applies to a transaction in progress and requires a presentation so that the [consumer] cannot help but become aware of the terms." ${ }^{.62}$

ALI Principles, supra note 3, $\$ 2.02$, cmt. c, at 127.

61 ALI Principles, supra note $3, \S 2.02 \mathrm{cmt} . \mathrm{c}$ at 127.

62 ALI Principles, supra note $3, \S 2.02 \mathrm{cmt}$. c at 128. 
Under subsection (c)(2), Raj must have reasonable notice of and reasonable access to the standard form after initiation, but before completion of the transaction so as to allow Raj to peruse the e-standard terms at any time during the process. Reasonableness typically would require a conspicuous notice of the availability of the standard form, so a notice that is itself hidden or in fine print would not satisfy (c)(2). Reasonable access ordinarily would mean that the consumer can reach the e-standard form either on the homepage or via a conspicuous hyperlink on the homepage. But to bind the consumer to the transaction at checkout, subsection 2.02(c)(3), which follows, requires a click wrap presentation.

\section{(c) Subsection 2.02(c)(3)}

To complete a transaction, subsection (c)(3) requires that Raj "signify" agreement to the e-standard terms. The subsection would be satisfied, if, for example, the "I agree" icon directly follows the standard form or is adjacent to it so that the presentation mirrors a paper transaction in which the consumer must sign at the end of the hard-copy document. Unlike this click wrap approach, a browsewrap presentation, such as where Raj would have had to click on a hyperlink at the bottom of a page to reach the Terms of Use, ordinarily would not satisfy this subsection: "Under subsection (c)(3), a mere screen reference to terms that can be found somewhere else on the site would be insufficient as would a scroll-down window containing the standard form if the 'I agree' icon is not at the end of or adjacent to the standard form." 63

\section{SUBSECTION 2.02(C)(4)}

Subsection (c)(4) ensures that Raj can print a hard copy of the e-standard terms and save them on a hard drive. ${ }^{64}$

\section{(a) Summary of the ALI Principles' Approach}

The following example, based on Illustration 5 to Section 2.02, lays out how a vendor can satisfy Section 2.02(c), subsections 1 through 4 :

Raj, a consumer, downloads a single copy of word-processing software manufactured by A, a software[licensor]. The standard form is reasonably accessible on the homepage of A's website prior to Raj's selection of A's software. Raj clicks "I agree" at

\footnotetext{
ALI Principles, supra note $3, \S 2.02$, cmt. c at 129.

64 Subsection (c)(4) is in part the approach of the Electronic Commerce (EC Directive) Regulations 2002 (2002) SI 2013, http://www.opsi.gov.uk/si/si2002/20022013.htm. Subsection 2.02(d) of the ALI Principles, not discussed in the text of this article, addresses another issue with both paper and e-standards forms, namely their use of legalese. The subsection requires comprehensible terms that are free from ambiguity and that avoids the use of overly technical jargon.
} 
the bottom of a standard form presented on a computer screen before the download [can begin]. ${ }^{65}$

Proof of notice and access at any of the stages of Internet shopping creates issues, but not insurmountable ones. Many vendors maintain archival records of their website content that specifies when screen material appeared, was modified, or was removed. ${ }^{66}$ Server logs offer additional proof. ${ }^{67}$ Finally, a visitor to a site whose identity is recorded on a web log can prove availability of a standard form on particular dates. ${ }^{68}$

Vendor A's e-standard terms would be enforceable so long as Raj can print a hard copy of the terms and save them on the consumer's hard drive. In addition, the terms must not be unconscionable or against public policy. Courts can develop factors to illuminate these principles as they will apply to terms such as dispute resolution, unilateral modification, privacy restrictions, and automatic renewal.

\section{CONCLUSION: THE NEED FOR CAUTION ABOUT ANY SOLUTION}

The website-disclosure provisions of Sections 2.02(b) and(c) of the ALI Principles should prove helpful in India and elsewhere in dealing with the lack of consumer reading of e-standard terms, but they do not guarantee success. Even as online shopping continues to develop in India I doubt that more exposure to e-standard terms will improve reading and shopping for terms very much:

"Many commentators are not optimistic about disclosure as a remedy for market failures in standard-form contracting. They have observed the relative failure of truth-in-lending and other disclosure legislation. In addition, they have noted that, notwithstanding disclosure, people still have rational reasons for failing to read their forms, decision-making processes that deter careful reading, and a limited ability to process all of the information they do read. In the software-contract setting, transferees also exhibit impatience and exuberance that stand in the way of a measured response to disclosed terms." ${ }^{69}$

The failure of consumers to read will continue to influence some vendors to draft heavy-handed terms.

\footnotetext{
65 See ALI Principles,supra note 3, $\$ 2.02, \mathrm{cmt} . \mathrm{h}$ at 133

66 ALI Principles, supra note $3, \S 2.02$, cmt. e at 132.

67 Id.

68 Id.

69 ALI Principles, supra note $3, \S 2.02, \mathrm{cmt}$. h at 133.
} 
The promise of the ALI approach, as mentioned, is that rating services/watchdog groups will spread the word about terms that overreach, but lawmakers should be cautious because the strategy will succeed only if the groups spring up and are effective in monitoring sites and spreading the word, for example, through the creation of a popular website. Even more worrisome, website disclosure has the potential to create a strong argument against finding unenforceable terms that are only marginally fair. For example, the unconscionability doctrine typically authorises courts to deny enforcement of terms only if the bargaining process is suspect and the terms are substantively unfair. If the vendor makes its terms available on the Internet, it can claim that the bargaining process passes muster in light of the availability and easy access to the e-standard terms. After all, consumers would have the opportunity to read and compare terms free of the excitement or pressure of a particular transaction. Terms that are only marginally fair substantively may therefore be immune from an unconscionability finding. ${ }^{70}$

However, regulators should select the approach to standard forms that shows the most net promise after considering costs, and advanced disclosure may be the best of many imperfect solutions. As we have seen, other solutions are expensive, disrupt market forces, and likely would not do much to increase consumer reading and understanding of terms. Further, despite the possible dilution of unconscionability protection, in the long run vendors under an enhanced disclosure regime should be wary of drafting unfair terms in the first place. Vendors should also be aware that the Internet provides a convenient and almost frictionless method of spreading the word about unfair terms. Vendors therefore may have the incentive to write better terms in the first place. ${ }^{71}$

In conclusion, let's briefly revisit my previous assumption that consumers in India engaged in e-commerce pay little attention to their e-standard terms. ${ }^{72}$ If I am wrong, and consumers' conduct more closely resembles cautious and deliberate Indian business contractors, the ALI approach still makes sense in India. After all, the heart of the ALI strategy is greater availability and accessibility of e-standard forms. Perhaps cautious e-consumers in India would take more time to read and compare terms before committing to purchases if Indian contract law facilitated the availability of the terms. Aware of the exposure of their terms to a sufficient number of readers that could influence vendor reputation and market share, vendors would have the incentive to draft reasonable terms. Of course, such a result would also favour non-reading Indian consumers who would avoid having to rely on ex-post litigation to preserve their rights. This is especially important in India where, at least presently, justice may be delayed. ${ }^{73}$

70 See Robert A. Hillman, Online Boilerplate: Would Mandatory Website Disclosure of E-Standard Terms Backfire? 104 Mich. L. Rev. 837 (2006).

71 Id.

72 See supra notes 9-12.

73 See supra note 12. 